2009

\title{
Improving Inter-Nation Equity through Territorial Taxation and Tax Sparing
}

Jinyan Li

Osgoode Hall Law School of York University, JLi@osgoode.yorku.ca

Follow this and additional works at: http://digitalcommons.osgoode.yorku.ca/all_papers

Part of the Taxation-Transnational Commons, and the Tax Law Commons

\section{Repository Citation}

Li, Jinyan, "Improving Inter-Nation Equity through Territorial Taxation and Tax Sparing" (2009). All Papers. Paper 252. http://digitalcommons.osgoode.yorku.ca/all_papers/252

This Working Paper is brought to you for free and open access by the Research Papers, Working Papers, Conference Papers at Osgoode Digital Commons. It has been accepted for inclusion in All Papers by an authorized administrator of Osgoode Digital Commons. 


\title{
Improving Inter-Nation Equity through Territorial Taxation and Tax Sparing
}

\author{
Jinyan Li
}

Professor, Osgoode Hall Law School, York University, Canada; and Senior Fellow, Taxation Law and Policy Research Institute, Monash University, Australia.

This article is dedicated to the memory of Professor Eason who supervised the author's LL.M thesis and introduced her to the fascinating world of international tax research.

This article benefits greatly from the comments received from participants of the "Globalization and the Impact of Tax on International Investments: A Symposium in Honour of the Memory of the Late Alex Easson” at Queen’s University, Feb. 29, 2008. The author thanks He Huang (LL.M candidate) and Shane Latvick (BLG Fellowship) for their research assistance. 
There is no real agreement as to what would be a proper division of the [international] tax base, nor is there any obvious principle of fairness that can be invoked to justify any particular distribution of revenue. The present division has been a more or less accidental result of the attempt to eliminate double taxation, and is principally a product of the various model double taxation treaties that have been adopted over a period of some 60 years. Since the principal architects of these model treaties have been the major capital-exporting countries, it seems reasonable to suppose that, to the extent that the existing arrangements are inequitable, they operate to the prejudice of countries that are primarily importers of capital ... and as the great majority of lesser-developed countries fall into this category, there is the further consideration that some redistribution in favour of source countries would on balance be desirable and would promote a form of vertical equity among nations.

--- Alex Easson (1991)

The current international tax system allocates the taxation of cross-border income by reference to the residence of the taxpayer and/or the source of income. The governing rules are contained in domestic tax laws and bilateral tax treaties. As noted by Professor 
Easson, the current regime of allocation is not based on any real agreement between nations and cannot be rationalized by any "obvious principle of fairness". In fact, it is biased in favour of the capital exporting nations that devised the rules of the game. In order to improve fairness, Professor Easson considered it desirable to have some "redistribution" in favour of less developed, net capital-importing nations. Professor Easson was one of few legal scholars ${ }^{2}$ that have emphasized the importance of internation equity. International tax literature has recently been preoccupied with efficiency and welfare maximization, ${ }^{3}$ predominantly from a one-country perspective. ${ }^{4}$

This paper joins Professor Easson in his pursuit of inter-nation equity. The main argument is that inter-nation equity in the sense of fair allocation of tax base as well as international redistribution should be taken seriously in future tax reforms. It demonstrates, at a conceptual level, that inter-nation equity can be improved through adopting a territorial system of taxing business income and redesigning the tax sparing system. The main goal of this paper is to tease out the conceptual challenge of identifying inter-nation equity without suggesting any specific mechanism or process by which it might conceivably be resolved.

The paper proceeds as follows. Part I provides a brief overview of the concept internation equity (INE) in terms of allocation of international tax base and a modest element of redistribution of tax base between nations. Part II makes the case for taking internation equity seriously in current international tax reforms. Part III demonstrates that a 
territorial system of taxing business profit is more equitable in sharing the tax base between the source country and the residence country of the capital-owner. It also demonstrates that the well-designed tax sparing system can function as a meaningful redistribution system between countries. The paper ends with some general conclusions.

\section{INTER-NATION EQUITY}

\section{A. The Concept}

Peggy Musgrave adopted the term "inter-nation equity” in her work published in the 1960s. In United States Taxation of Foreign Investment Income (1969) ${ }^{5}$ she writes that “international revenue sharing, as an aspect of the taxation of foreign investment, is a matter of inter-nation equity”, and that "[a]lthough this problem is of little interest to the

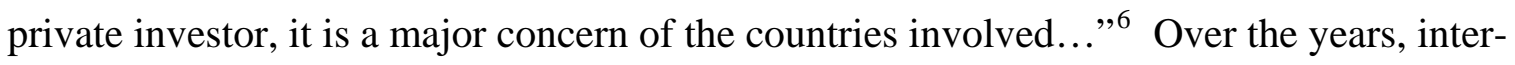
nation equity has been variously described by Peggy and/or Richard Musgrave as an "equitable division of the tax revenue between countries,"7 "the problem of tax shares in international business,”8 and an equitable “allocation of national gain and loss.”9

Legal scholars have phrased inter-nation equity to be the "distribution among countries of the competence to tax". 10 “A major goal of international tax rules should be to provide 
each country of the world with a fair share of the tax revenues available from income generated by transnational activities of domestic and foreign taxpayers.”11

As such, inter-nation equity differs from the other, and better known, notion of "equity" inter-individual equity based on the ability to pay principle. Inter-individual equity is concerned with the sharing of the tax burden among taxpayers in a country (which can be understood as "intra-nation equity”), whereas inter-nation equity is an international problem and is concerned with the sharing of the tax base between nations. Inter-nation equity is also different from international neutrality (capital-import neutrality or capital export neutrality) or international efficiency. International tax neutrality toward investment may be defined "as a situation in which the pattern of taxation does not interfere with or affect the taxpayer's choice between investing at home and investing in foreign countries." ${ }^{12}$ It is "called for in the interests of world efficiency in resource allocation.”13 Leaving patriotism aside, taxpayers are directly affected by inter-individual equity and international neutrality, but not inter-nation equity.

\section{B. Tax Entitlement and Allocation of International Tax Base}

According to Peggy Musgrave, the notion of "national entitlements" is the basis for internation equity. In her early work, Musgrave regarded inter-nation equity between the home and host countries in terms of an equitable division of national gain and loss. ${ }^{14} \mathrm{~A}$ taxpayer's income from foreign investment is part of the home country's national gain 
because the home country has an initial interest in all of its taxpayers' capital and incomes. An income tax imposed by a host country thus results in a national loss to the home country. Whether the home country also experiences a loss of revenue or "treasury loss” depends on the method used by it to prevent double taxation. If the home country uses the exemption method or credit method, the host country's tax diminishes the home country's treasury, thus resulting in a "national loss". The home country's national loss is a national gain to the host country. Musgrave's recent work focuses more on the tax entitlement of both the residence country and source country and the notion of sovereignty. ${ }^{15}$

In discussing the tax entitlement of the residence country, Musgrave states that "countries will wish to retain a degree of sovereignty over the tax treatment of the income-earning activities abroad of their residents." ${ }^{16}$ She advances several principles in support of the residence country's tax entitlements. One is economic allegiance: “residents are held to owe tax allegiance in return for the rights and privileges that they receive as residents”. Another is the ability-to-pay principle: "exercise of tax sovereignty over foreign source income is also necessary to achieve equitable tax treatment of resident taxpayers by making all income, wherever earned, subject to tax, consistent with the accretion principle.” ${ }^{17}$ The third is the benefit principle: "as a payment for productivity-enhancing benefits provided by the country of residence to its own factors of production prior to transfer abroad and for the rights and privileges afforded the corporation by its country of registration.” ${ }^{18}$ National interest may also be relevant in determining whether outflow of 
capital should be encouraged or discouraged. Ultimately, the residence country’s tax entitlement is only residual. However, as a residual taxing authority, the residence country has control over the total tax burden of the foreign-source income of its resident taxpayers. An exemption system would leave the foreign income taxed solely by the source country, whereas a credit system may result in some tax payable to the residence country if the foreign tax is lower. In the absence of cooperation the principal consideration in making the choice are equitable.

Source countries are entitled to tax income arising within their borders, including that accruing to foreign investors. Musgrave regards this entitlement to tax at source as "the bedrock of most international tax treaties."19 A country is permitted "to share in the gains of foreign-owned factors of production operating within its borders, gains that are generated in cooperation with its own inputs, whether they be natural resources, an educated or low-cost workforce, or proximity to a market.”20 She rationalizes the source country’s entitlements on the basis of “economic rent” -the source country’s tax "may be thought of as a national return to the leasing of these complementary factors to nonresident investors or temporary workers.” She also thinks of source country tax in benefit terms, as a quid pro quo payment for cost-reducing, profit-enhancing services provided by the source country." 21

Musgrave's formulation of inter-nation equity suggests that source entitlement and residence entitlement stand on equal footing. Any inter-nation tax conflicts should be 
resolved through international coordination, as opposed to tax competition. Her primary issue in inter-nation equity is the source country’s share in international income arising within its borders.

\section{Inter-nation Redistribution}

The notion of inter-nation equity emphasizes fair allocation of tax base among countries. The Musgraves did raise a concern about distributional consequences: “[w]ith a highly unequal distribution of resource endowments and per capita income among countries and in the absence of an adequate method for dealing with the problem, an appropriate pattern of tax-imposed national gains and losses might be used to secure some degree of adjustment.”22 They suggested a mechanism for redistributing wealth internationally - an internationally agreed rate schedule for corporate tax and withholding tax wherein tax rates would relate inversely to per capita income in the source country and directly to per capita income in the residence country. ${ }^{23}$

The Musgraves did not provide any theoretical foundation for inter-nation redistribution. In recent years, John Rawls’s theory of justice has been applied to inter-nation distributive justice, in spite of Rawls’ own reticence in this regard. Rawls’ central argument for domestic distributive justice is that individuals should not be disadvantaged on account of arbitrary factors such as their social class, natural endowment, and misfortune. ${ }^{24}$ Global egalitarians have argued that neither should individuals be at a 
disadvantage due to an accidental fact like their country of birth. ${ }^{25}$ If distributive justice is motivated by the need to mitigate the effects of contingencies that are "arbitrary from a moral point of view” on people’s life chances, this presents a consideration also for global distributive justice. ${ }^{26}$ Some legal scholars recognize that globalization has increased the need for inter-nation redistribution ${ }^{27}$ and argue that there appears to be no sound theoretical reason to restrict redistribution to members of any single tax jurisdiction. ${ }^{28}$ Others argue, however, that effective redistribution needs a world government. ${ }^{29}$ In the absence of such world government, ${ }^{30}$ a systematic redistribution is unlikely. Nonetheless, redistribution between nations is becoming an increasingly important concern and the tax system has a role to play.

\section{WHY SHOULD EQUITY BE TAKEN SERIOUSLY NOW?}

Inter-nation equity in terms of allocating the international base in accordance with the tax entitlements of each country and re-distributing national income in accordance with distributive justice should be taken seriously in international tax reforms for two main reasons. One, it provides an important, and perhaps superior, policy framework than the principle of neutralities to guide future reforms. Second, the inequities in the international tax system are difficult to justify, let alone, perpetuate, in the age of globalization. Inter-nation equity provides a rationale and goal for reforms to reduce such inequities. The beginning of a new millennium is the right to act. 


\section{A. Important Policy Criteria}

Tax equity has been an important policy objective in domestic income tax policy. However, recent proposals to reform international tax system in Canada, New Zealand, United Kingdom, and United States ${ }^{31}$ have focused on economic efficiency, almost to the exclusion of all other values, as a criterion for international tax policy. ${ }^{32}$ For example, the Advisory Panel of Canada's System of International Taxation recently published a consultation paper -- Enhancing Canada's International Tax Advantage ${ }^{33}$ identifies the policy framework to include attracting foreign investment, competitiveness, simplicity, and fairness. It recognizes the theories of capital export neutrality (CEN), capital import neutrality (CIN) and capital ownership neutrality (CON) may influence the choice between an exemption system and a foreign tax credit system. Indeed, the Advisory Panel expressed a preference for the exemption system over the credit system, mainly on ground of CIN and CON. ${ }^{34}$ The recent debates about the exemption or credit system of taxing foreign business profits have been described as the "Battle of the Neutralities. ${ }^{35}$

Relying on CEN, CIN and CON as guiding principles for international tax policy suffers several shortcomings: 
(1) As recognized by the Panel, "fulfilling the three neutrality standards with a single set of tax rules is impossible.”36 Either a credit system or an exemption system violates at least one of the principles.

(2) The conflicts between CEN and CIN/CON cannot be reconciled in the absence of harmonization of every country's tax rates. The Carter Commission argues that neutrality requires tax harmonization between nations so that each individual is unaffected, from a tax viewpoint, by citizenship, residence, and the locations of property, business, and employment. ${ }^{37}$ Of course, such harmonization is possible only if all countries provide the same public expenditures mix, finance with the same taxes at the same rates, and adjust the taxes simultaneously. Since one of such criteria is unlikely to be met in practice, international neutrality cannot be achieved. Even if tax harmonization were possible, the Commission notes that tax revenues must still be allocated between source and destination countries, and in a world of other distortions international neutrality may not be a sensible goal. ${ }^{38}$

(3) There are disagreements as to what is needed to satisfy CIN or CEN. Traditionally, CEN is considered satisfied by the accrual taxation or deferral plus credit system, ${ }^{39}$ and CIN is satisfied by the exemption system. Recently, some scholars argue that exclusive source-based taxation (or territorial taxation) "seems to be a theoretically, practically, and politically superior means for achieving CEN.”40

(4) The practical implications of CIN and CEN are not as significant as they appear. OECD countries generally impose some sort of accrual taxation of foreign portfolio income (similar to the Canadian FAPI system). The apparent difference 
between deferral plus credit system (CEN-based) and the exemption system (CIN based) results in little real difference if foreign business income earned through a foreign corporation is not repatriated (that is, if the deferral lasts long enough). In certain circumstances, because of the time value of money, the credit system produces tax results that are better than the exemption system. ${ }^{41}$

Therefore, the neutrality principles justify almost any proposal of reform: “[E]very traditional discussion concludes by asserting that whatever policy is being proposed represent a fair balance between those two irreconcilable objectives [CIN and CEN], in every case based largely on the author's preexisting intentions." ${ }^{42}$ It is time to take INE seriously. Compared to the neutrality principles, the ability-to-pay and tax entitlement principles that underlie inter-nation equity are more coherent internally and offer a rational framework for the debate. For example, the ability-to-pay principle has been accepted as a guiding principle in the development of personal income taxation, even though the level of progressivity may have been controversial. Furthermore, tax entitlement (although a much less debated issue in tax literature) has formed the bedrock

of the current tax treaty network. ${ }^{43}$ At a minimum, the ability-to-pay principle and tax entitlement principle should be considered.

\section{B. Equity as a Benchmark for Reducing International Tax Inequities}


The unfairness and inequities in the current international tax system have been well identified in literature. For example, Easson noted that tax treaty rules have been developed by major capital-exporting countries and operate to the prejudice of developing countries. ${ }^{44}$ Inter-nation equity can function as a benchmark for measuring inequities as well as a goal for reforms.

The bias against capital-importing countries is evident in the history of the world's tax treaties. ${ }^{45}$ Current tax treaties are based on the model tax conventions developed by the OECD and the UN to a lesser extent. These treaties were originally developed primarily to eliminate double taxation in order to facilitate cross-border trade and investment. The elimination of double taxation is achieved mainly through restrictions on source taxation. Treaty rules have the appearance of fairness because they are “reciprocal”. However, as between a developing and a developed country, such reciprocity exists only in name, because the developing country is a net-capital importing country. As such, any limitation on source taxation reduces its tax base. ${ }^{46}$ In the case of business income and income from real estate where the tax entitlement of a source country is overwhelmingly strong, inter-nation equity would require exclusive taxation of such income in the source country.

As noted by Peggy Musgrave that some redistribution of income between countries is necessary in order to reduce the inequity resulted from allocating international tax based in accordance with the tax entitlements because of the unequal natural endowments of resources, etc. The need for such international redistribution is increasing because the 
income gap between high-income and low-income countries has been increasing. International inequity is evidenced by the fact that $23 \%$ of the world's inhabitants absorb a whopping $82 \%$ of the world's wealth as measured by gross domestic products (GDP), leaving $77 \%$ of the world to divide the remaining $18 \% .{ }^{47}$ Such inequity "dwarfs into relative insignificance” the domestic distributive problem. ${ }^{48}$ Since income tax has been used as an effective instrument for redistributing income at a national level through progressive taxation and various social tax expenditures, international income tax policy could be used as a distributive instrument, albeit at a modest level. Tax treaties are currently capable of redistributing the tax base whereby a high-income (residence) country "transfers" its jurisdiction to tax to the low-income (source) country (such as high withholding tax rates for investment income) or grants a tax sparing.

\section{Opportune Time}

The wheels of international tax reform churn slowly. At the beginning of the new millennium, there appear to be forces that may speed up the reform. One force is the increasing influence of the OECD as a de facto world tax organization. ${ }^{49}$ The OECD can play a significant role in coordinating the domestic tax policies of its member countries. Its influence goes far beyond its membership. Through providing technical assistance to non-member countries (such as China), maintaining and updating the OECD Model and Commentaries, developing transfer pricing guidelines, and publishing policy papers, the OECD exerts a great deal of influence on the tax policies of non-member countries. 
Should the OECD recognize the importance of inter-nation equity, it can mobilize forces to do something about it.

Another force for change is domestic reforms. Major reform initiatives in Canada and other OECD countries are likely to shift the system of taxing foreign business profits towards an exemption or territorial system. As discussed below, such shift should have positive implications for inter-nation equity. Recent developments in corporate tax in the EU suggest that equity and fairness in sharing the international corporate tax base is being taken seriously. ${ }^{50}$ The outcome of the EU reforms may suggest technical solutions. Tax reforms in low-income capital importing countries, such as China, have also demonstrated a maturity in their international tax policy. For example, as of January 1 , 2008, China abolished tax incentives that were designed in the 1980s and 1990s to attract FDI and replaced them with general lower rates and tax incentives designed to promote sustainable economic development. ${ }^{51}$ The new Chinese tax law also emphasizes the protection of the tax base through specific and general anti-avoidance rules (including transfer pricing and thin capitalization) as well as defining the Chinese source of income on the basis of the economic activities to reflect the Chinese view of tax entitlement.

There is also an emerging body of tax scholarship on inter-nation equity. ${ }^{52}$ Tax scholars have studied and applied the principle of inter-nation to the analysis of international tax problems, such as the taxation of corporate income, ${ }^{53}$ tax jurisdiction, ${ }^{54}$ tax sparing, ${ }^{55}$ 
and redistribution across borders. ${ }^{56}$ It is possible that some of the academic insights are translated into reforms in domestic and or treaty law to achieve more equity.

\section{TAX REFORMS TOWARDS INTER-NATION EQUITY}

\section{A. The role of high-income countries}

Any improvement in inter-nation equity must be initiated and supported by capitalexporting countries because they have the obligation and capability. There is a growing awareness that the North-South divide "lies at the heart of the rich world's current troubles, including terrorism, immigration pressures, and environmental threats”. ${ }^{57}$ These global problems cannot be resolved by the South alone. Members of the United Nations have unanimously agreed that the inequities must be addressed internationally and

pledged themselves to achieve the "Millennium Development Goals" by 2015. ${ }^{58}$ Although developed countries have not fulfilled their obligations, there is no denying that there is a recognition of the need for global justice and the intention of doing something about it. Ultimately, reducing inequity serves the interest of developed countries as well. Many developed countries are sympathetic to the claim for more source-based taxation by developing countries and have adopted the provisions of the UN Model Convention at various degrees, including tax sparing. 
Low-income countries have not played any meaningful role in developing the current international tax system. They do not have an institution, such as the OECD, that can effectively represent their tax interests. The United Nations has not functioned as a world tax organization in any sense. Moreover, low-income countries have been competing with each other in offering tax incentives to FDI, ${ }^{59}$ even if the effectiveness and efficiency of many tax incentives are doubtful. It seems difficult for these countries, as a group, to end the "race-to-the-bottom" type of tax competition on their own. The OECD’s initiative on harmful tax competition, although motivated mostly out of selfinterest of its member countries, seems to have encouraged some tax haven countries to cooperate with OECD member countries. ${ }^{60}$

In terms of actually implementing any change of reform, only developed countries have the capacity. As mentioned already, the OECD is the closest thing we have as an “international tax organization”. ${ }^{61}$ OECD Member countries that provide homes for about three quarters of the world's multinational enterprises and whose citizens account for well over half of the world income and wealth - The "rich holds the key to taxation reform., ${ }^{, 2}$

\section{B. Territorial Taxation of Business Income}

The current system of international taxation recognizes the tax entitlement of the source country in respect of business profits derived from activities carried on in that country. 
Foreign business profits earned directly by a domestic corporation are taxable in the source country under bilateral treaties to the extent that they are attributable to a permanent establishment in the source country. ${ }^{63}$ Whether such profits are taxed again in the residence country depends on that country's domestic tax law. In "credit” countries (e.g., Australia, Canada, Japan, UK, and US), the profits are taxable, subject to a foreign tax credit for the source country's tax. ${ }^{64}$ In "exempt" countries (mostly continental European countries), such profits are exempt from domestic taxation. As a result, the only difference between the credit system and the exempt system is whether the residence claims "residual" taxation over the foreign business profits. Therefore, if the residence country adopts the credit system and limits the credit to the amount of domestic tax otherwise payable, it implicitly allows the source country to tax income at the "soak-up" rate (i.e., a rate that is equal to that in the residence country). If the residence country adopts the exemption system, it gives the source country exclusive jurisdiction to tax.

Where foreign business profits are earned through a foreign corporation owned by domestic residents, such profits are taxable solely in the source country. The residence country of the shareholder does not tax such profits on a current basis, irrespective of it is a credit country or an exempt country. However, when the profits are repatriated to the shareholders by way of a dividend, the taxation of the dividend differs between a credit country and an exempt country. The former would tax the dividends, subject to a direct and indirect foreign tax credit for the foreign dividend withholding tax and underlying corporate income tax. The latter would exempt the dividends from domestic taxation. 
Canada has a hybrid credit and exemption system: the latter applies on to business profits earned in a treaty country. However, the "credit" or "exempt" treatment is limited to the corporate shareholder of the foreign corporation. When the domestic parent corporation distributes the dividends received from its foreign subsidiary to individual shareholders, the dividends are generally taxable under personal income tax. In this sense, both credit and exempt countries "share" the taxation of business profits, albeit on a deferred basis, by taxing the individual shareholders on the repatriated profits.

The exempt system is gaining support in economic literature and many international tax reform recommendations in Australia, Canada, New Zealand, United Kingdom, and the United States. In principle, the exemption system allows business profits to be subject to territorial taxation. Territorial taxation is consistent with the tax entitlement theory and promotes inter-nation equity. Business profits earned in the source country are taxed exclusively at source at the corporate level, and again at the individual shareholder level in the residence country. Assuming that the source rules and allocation rules are "scientifically" designed to reflect the economic origin of business profits, the countries that are entitled to tax such profits (i.e., the source country and the residence country of the individual investor) share the taxation of business profits.

One drawback of territorial tax system is the risk of encouraging tax competition among source countries because the level of corporate-level tax would be exclusively determined by the source country. ${ }^{65}$ The territorial system allows the foreign investor to directly 
benefit from the tax incentives granted by a source country, whereas a credit system would "cancel" the benefits of tax incentives by taxing the business profits in the absence of a tax sparing credit.

While territorial taxation of business profits promotes inter-nation equity, the same cannot be said with territorial taxation of investment income. ${ }^{66}$ The tax entitlement claims of the source country over investment income are not nearly as strong as over business income. The residence country of the investor has, in fact, a much stronger claim. The goal of inter-nation equity is met if the residence country has the dominant, if not exclusive, tax claim over international portfolio income. As such, the Canadian FAPI regime, the U.S. Subpart F regime, and similar anti-deferral or imputation system of taxing foreign passive income earned by controlled foreign corporations do not violate inter-nation equity. ${ }^{67}$

\section{Tax Sparing as a mechanism of International Redistribution}

A tax sparing credit is, in essence, a credit for foreign taxes deemed paid for the purposes of claiming foreign tax credit by the taxpayer in the residence country. Naturally, it is relevant only when the residence country adopts the credit system of taxing foreign income. If the residence country adopts the territorial system of taxation for business profits, the tax sparing credit would be relevant only in the case of international portfolio 
income. Otherwise, it would be relevant in case of both foreign business income and portfolio income.

The country that grants a tax sparing credit recognizes the tax entitlement of the source country and supports the use of tax incentives by foregoing its residual tax claim over the income that was exempt from tax in the source country. In other words, this is a crossborder tax subsidy, that explicitly benefits the taxpayer who invests in the source country, but implicitly benefits the source country by "subsidizing" the investment. Because a tax sparing credit is generally given by a high-income capital exporting country to a lowincome capital importing country through treaty negotiations, it can be viewed as international redistribution mechanism.

There have been significant debates about the merits of tax sparing credits. Among the many criticisms of this mechanism are the lack of transparency and accountability, potential for abuse, and lack of a sun-set clause. ${ }^{68}$ However, these criticisms seem to point to technical design issues, not the theoretical rationale. Until an explicit international redistribution system is established, abolishing tax sparing would remove the only mechanism we have of international redistribution. ${ }^{69}$

Instead of abolishing it, capital-exporting countries should re-design the tax sparing mechanism to effectively deliver aid to "worthy" countries in respect of "worthy" investment activities. ${ }^{70}$ For example, tax sparing can be targeted at the incentives used to 
“jump start” an economy in the form of FDI or the transfer of technology. Such

mechanism would be an effective way of assisting the developing country without unduly “encouraging” harmful tax competition.

\section{CONCLUSIONS}

A number of conclusions can be drawn on the basis of the discussions in this paper. First, inter-nation equity in the sense of fair sharing of the international tax base has been the foundation of the current international tax system, but there are significant inequities towards net capital-importing countries. Intern-nation equity in the sense of redistribution between nations has not been taken seriously. Second, inter-nation equity deals with the sharing of the international tax base between countries, and does not, in theory, adversely affect the allocation of resources or investors' behaviour. There appears to be no sound reasons to regard world efficiency and world equity as mutually exclusive. Third, in the age of globalization, there are many international problems that can be effectively addressed only by international efforts. As part of the international legal system, the tax system has a role to play. High-income countries have the means and obligation to affect changes to the international tax system in order to achieve equity. Adopting territorial system of taxation and effective tax sparing credits are possible examples. 


\section{Notes:}

${ }^{1}$ Alex J. Eason, International Tax Reform and the Inter-Nation Allocation of Tax Revenue (Victoria University Press, Wellington, New Zealand 1991), 20.

${ }^{2}$ Other scholars and their work include: Nancy Kaufman, 'Fairness and the Taxation of International Income,' Law and Policy in International Business 29 (1998):145-203; Klaus Vogel, 'World-wide vs. Source Taxation of income - A Review and Reevaluation of Arguments,' in Influence of Tax Differentials on International Competitiveness: Proceedings of the VIIIth Munich Symposium on International Taxation (Deventer, Boston: Kluwer Law and Taxation Publishers 1991), 160-61; Jinyan Li, Taxation in the Age of Electronic Commerce: A Comparative Study (Toronto, Canadian Tax Foundation, 2003), ch.12.

${ }^{3}$ This is noted by legal scholars, such as J. Clifton Fleming, Jr., Robert J. Peroni and Stephen E. Shay, 'Fairness in International Taxation: The Ability-to-pay Case for Taxation Worldwide Income, Florida T. Rev. 5 (2001), 299; and Michael J. Graetz, ‘Taxing International Income: Inadequate Principles, Outdated Concepts, and Unsatisfied policies,' Brooklyn J. Int'l L 26 (2001), 1357.

${ }^{4}$ For an overview of the literature on international tax neutrality, see Fadi Shaheen, 'International Tax Neutrality: Reconsiderations,' Va. Tax Rev. 27 (2007), 203; James R. Hines Jr., ‘The case Against Deferral: A Deferential Reconsideration,' Nat'l Tax J. 52 (1997 385; and Mihir A. Desai and James R. Hines Jr., 'Evaluating International Tax Reform,’ Nat’l Tax J. 56 (2003) 487.

${ }^{5}$ Peggy B. Musgrave, United States Taxation of Foreign Investment Income: Issues and Arguments (Cambridge, Harvard Law School 1969) 130-33.

${ }^{6}$ Musgrave, United States Taxation of Foreign Investment Income (1969) 133 and 130.

${ }^{7}$ Peggy Brewer Richman (later Musgrave), Taxation of Foreign Investment Income - An Economic Analysis (John Hopkins Press 1963) 49; and Richard A. Musgrave, Fiscal Systems (1969) 238.

${ }^{8}$ Peggy B. Musgrave, 'International Tax Base Division and the Multinational Corporation,' (1972) 27 Public Finance 27 (1972) 394; 'Interjurisdictional Equity in Company Taxation: Principles and Applications to the European Union,' in Sijbren Cnossen, ed., Taxing Capital Income in the European Union: Issues and Options for Reform (Oxford, Oxford University Press, 2000) 47-77; 'Consumption Tax 
Proposals in an International Setting,' Tax L. Rev. 54 (2000) 77-100; 'Sovereignty, Entitlement, and Cooperation in International Taxation,' Brooklyn J. Int'l L. 26 (2001) 1335-1356; and 'Combining Fiscal Sovereignty and Coordination: National Taxation in a Globalizing World,' in Inge Kaul and Pedro Conceicao, ed. The New Public Finance Responding to Global Challenges (Oxford University Press 2006) 167.

${ }^{9}$ Peggy B Musgrave and Richard A. Musgrave, 'Inter-Nation Equity,' in Richard M. Bird and John G. Head, eds., Modern Fiscal Issues (Toronto: University of Toronto Press, 1972) 63-85, at 68; Peggy B. Musgrave and Richard A. Musgrave, 'Fiscal Coordination and Competition in an International Setting,' in L. Eden, ed., Retrospectives on Public Finance (Durham, NC: Duke University Press, 1991) 61-85, at 65-6. ${ }^{10}$ Kaufman, 'Fairness and the Taxation of International Income,' (1998); and Vogel, 'World-wide vs. Source Taxation of income,' (1991) 160-61.

${ }^{11}$ Brian J. Arnold and Michael J. McIntyre, International Tax Primer $\left(2^{\text {nd }}\right.$ ed) (The Hague, Kluwer Law Int'l 2002) 4.

${ }^{12}$ Musgrave, United States Taxation of Foreign Investment Income, at 109.

${ }^{13}$ Ibid.

${ }^{14}$ See Musgrave and Musgrave, 'Inter-Nation Equity,' 70-71,

${ }^{15}$ Musgrave, 'Combining Fiscal Sovereignty and Coordination.'

${ }^{16}$ Ibid., 168.

${ }^{17}$ Ibid.

${ }^{18}$ Ibid.

${ }^{19}$ Ibid., at 172.

${ }^{20}$ Ibid.

${ }^{21}$ The source country has two primary instruments for exercising its tax entitlement through first defining the source rules and then the tax rate. In the absence of international cooperation, each source country will tend to choose policy options to serve its own interests. With respect to tax rate, source countries may engage in tax competition by lowering tax rates in order to attract foreign investment. Such tax competition 
will lead to the result that no capital-importing country obtains enough additional investment from abroad to justify the lower tax. Tax competition among source-country is facilitated by the residence country's tax rules that either exempt foreign income from tax or treat foreign taxes as deductible costs because these rules leave foreign investment flows open to variations in tax rates of the source countries. Musgrave considers source country tax competition as highly problematic for developing countries because of the damaging effects of such competition on domestic tax equity, badly needed tax revenue. 'The share of the tax base and the tax rate applied by source countries to income accruing to others should be viewed as a matter of international equity, calling for international cooperation,' Ibid., 173.

${ }^{22}$ Musgrave and Musgrave, 'Inter-nation Equity,' 71-72.

${ }^{23}$ Ibid., 74. P. Musgrave further argues that such a scheme would be of particular interest in the relation between developed and developing countries: Musgrave, 'Interjurisdictional Equity in Company Taxation,' (2000) 59.

${ }^{24}$ John Rawls, A Theory of Justice (Cambridge, MA: Harvard University Press, 1971) 15.

${ }^{25}$ See Charles R. Beitz, Political Theory and International Relations (Princeton, NJ: Princeton University Press, 1979) Part III; Thomas W. Pogge, Realizing Rawls (Ithaca, NY: Cornell University Press, 1989) Part III. See also Allen Buchanan, Justice, Legitimacy, and Self-Determination (Oxford: Oxford University Press, 2004) ch.4; Simon Caney, Justice Beyond Borders (Oxford: Oxford University Press, 2005); and Koh-Chor Tan, 'The Boundary of Justice and the Justice of Boundaries: Defending Global Egalitarianism,' Canadian J. of Law \& Jurisprudence 19 (2006) 319.

${ }^{26}$ Tan, ibid. Anti-global distributive justice scholars do not reject the duty of humanitarian assistance or the duty of rescue and denounce the current global economic arrangement as unacceptable because many people continue to be deprived of basic and urgent needs under this arrangement. However, they argue that the boundary of distributive equality is inherently limited by the boundaries of states. For example, Richard W. Miller, 'Cosmopolitan Respect and Patriotic Concern,' Phil. \& Pub. Affairs 27/3 (1998) 202; David Miller, ‘Against Global Egalitarianism,' J. Ethics 9-1-2 (2005) 55; Thomas Nagel, ‘The Problem of Global Justice,' Phil. \& Pub. Affiars 33/2 (2005) 113; John Rawls, The Law of Peoples (Cambridge, MA: Harvard 
University Press, 1999) Part III; and Samuel Freeman, Justice and the Social Contract: Essays on Rawls (New York: Oxford University Press, 2006). See also Jim Chen, 'Fugitives and Agrarians in a World Without Frontiers,' Cardozo L. Rev. 18 (1996) 1031 and 1040 ('The nation state ... excels at redistributing wealth through complex decisions to tax and to subsidize.'); Edward B. Foley, 'The Elusive Quest for Global Justice,’ Fordham L. Rev. 66 (1997) 249, 260 (“[T]he demands of global justice can never be as extensive as the demands of social justice within each nation-state”).

${ }^{27}$ See, e.g., Michael A. Livingston, ‘Blum and Kalven at 50: Progressive Taxation, “Globalization,” and the New Millennium,' Fla. Tax Rev. 4 (2000) 731.

${ }^{28}$ E.g., Karen B. Brown, ‘Can Cross-Border Distribution Serve the Caribbean Region?’ http://taxprof.typepad.com/taxprof_blog/2007/11/brown-delivers-.html (Nov.14, 2007) (arguing that crossborder tax policy should encompass cross-border distributive justice goals); Reuven Avi-Yonah, 'Globalization, Tax Competition, and The Fiscal Crisis of the Welfare State,' Harvard L. Rev. 113 (2000) 1573, at 1649. A similar sentiment was expressed by Easson, supra note 1.

${ }^{29}$ Some argue that it is not even desirable to have a world government because it "would likely become a dictatorship. In the absence of a world government, "the freedom and independence, as well as the economic welfare, of people varies from nation to nation”: see Graetz, ‘Taxing International Income: Inadequate Principles, Outdated Concepts, and Unsatisfied policies,' 278.

${ }^{30}$ There is no global authority or government to enforce the terms of distributive justice in the global arena - 'covenants, without the sword, are but words.' Tan, 'The Boundary of Justice and the Justice of Boundaries,' 322.

${ }^{31}$ See, e.g., Advisory Panel on Canada’s System of International Taxation, Enhancing Canada's International Tax Advantage (April 2008); U.S., Department of the Treasury, Office of Tax Policy, Approaches to Improve the Competitiveness of the U.S. Business Tax System for the $21^{\text {st }}$ Century (December 2007); UK, HM Treasury and HM Revenue \& Customs, Taxation of Companies’ Foreign Profits: Discussion Document (June 2007); Department of the Treasury, Australia, Review of Intrenational Taxation Arrangements: A Consultation Paper (August 2002); Inland Revenue Department, Policy Advice 
Division, New Zealand's International Tax Review: A Direction for Change (December 2006); and Inland Revenue Department, Policy Advice Division, and New Zealand Treasury, New Zealand's International Tax Review: Developing an Active Income Exemption for Controlled Foreign Companies (October 2007). For an overview, see Sandra Slaats, 'Financing Foreign Affiliates: An Overview of the Canadian Proposals and the Rules in Selected Countries,” Canadian Tax J. 55 (2007) 676.

${ }^{32}$ UK, Taxation of Companies' Foreign Profits: Discussion Document, 9-10. The focus on neutralities and competitiveness in international tax reforms can be traced to the 1960s when the current Subpart F rules were debated, which provided a blue print for other OECD countries’ controlled foreign corporation (CFC) rules.

${ }^{33}$ Advisory Panel on Canada's System of International Taxation, Enhancing Canada's International Tax Advantage, available at http://www.apcsit-gcrcfi.ca/05/cnpden-eng.html.

${ }^{34} \mathrm{CEN}$ generally requires current taxation of foreign income with a full credit for foreign taxes paid. To the extent that foreign taxes are less than domestic tax, the tax base is shared between the source country and the residence country of the shareholder. CIN and CON call for the primary or exclusive taxation of business income in the source country. This is often referred to as the 'exemption' system or territorial system. In practice, no country has adopted a pure credit system or a pure exemption system. The mix of the two systems attempts to balance between CEN and CIN/CON.

${ }^{35}$ This term is borrowed from Edward D. Kleinbard, ‘Throw Territorial Taxation from the Train,' Tax Notes (February 5, 2007) 547 at 555.

${ }^{36}$ Advisory Panel on Canada's System of International Taxation, Enhancing Canada's International Tax Advantage, 11.

${ }^{37}$ Canada, Royal Commission on Taxation (Chair: K. Carter), Report, vol. 4 (Ottawa: Queen’s Printer, 1966), at 483-84 (hereinafter “Carter Report”) 491-96.

${ }^{38}$ Ibid.

${ }^{39}$ See Musgrave, United States Taxation of Foreign Investment Income, 121 (arguing that only unlimited foreign tax credit system satisfies CEN). Others have defended the 'deferral plus credit' (with limitations) 
on grounds of CEN. See, for example, US Treasury Department, The Deferral of Income Earned Through U.S. Controlled Foreign Corporations: A Policy Study (2000) 23-26.

${ }^{40}$ According to Shaheen, the pure residence-based worldwide taxation system satisfies CEN only when global uniformity with respect to tax systems is achieved: Shaheen, 'International Tax Neutrality: Reconsiderations,' 225-8.

${ }^{41}$ See Lawrence Lokken, 'Territorial Taxation: Why Some U.S. Multinationals May Be Less Than Enthusiastic About the Idea (and Some Ideas They Really Dislike),' S.M.U.L.Rev. 59 (2006) 751-72 (discussing why the credit system often allows US multinational corporations to achieve US tax results more favorable than they could obtain under an exemption system). Lokken attributes such favorable results to the numerous tax minimization techniques used by US corporations, including one technique that is used to separate foreign income taxes from income on which those taxes were imposed through the use of hybrid entity under the check-the-box rules.

${ }^{42}$ Kleinbard, ‘Throw Territorial Taxation from the Train,’ 555.

${ }^{43}$ Musgrave, 'The OECD Model Tax Treaty: Problems and Prospects,' Columbia J. of World Business (Summer 1975) 29.

${ }^{44}$ Easson, International Tax Reform and the Inter-Nation Allocation of Tax Revenue, at 20. This view is consistent with the observations in the general regulatory competition literature that states seeking to form international regimes may purchase consensus among key actors through biasing the distribution of benefits and burdens to their advantage. See Robert O. Keohane, Power and Governance in a Partially Globalized World (Routledge: London, 2002).

${ }^{45}$ Tax treaties are primarily based on the OECD Model, which itself was largely based on the structure and concepts developed by the League of Nations. Among the various model conventions developed by the League of Nations, the Mexico Model was the only one that gave more source jurisdiction, but was not followed in subsequent models. The OECD Model generally prefers residence based taxation and assigns exclusive taxing rights to the residence country in respect of royalties, international shipping income, and 'other income.' The 1980 UN Model was developed as a response to concerns by developing countries that 
the OECD Model gave too much emphasis on residence taxation and not sufficient emphasis to source taxing rights. Accordingly, as a general matter the UN Model confers greater taxing rights on the source country than the OECD Model). In practice, however, the UN Model has not reduced the bias against developing countries in any meaningful way because it shares the same structure, concepts and principles of the OECD Model. This is consistent with the history of trade and investment. See, for example, Frank J. Garcia, ‘Trade and Inequality: Economic Justice and the Developing World’ (1999-2000) 21 Mich. J. Int’l L. 975, at 982-4. For the League of Nations and OEEC (predecessor of the OECD) material on income tax conventions is reproduced in Joint Committee of Internal Revenue Taxation, Legislative History of United States Tax Conventions (U.S. Government Printing Office, 1962), Vol.4, 'Model Tax Conventions’, available at http://setis.library.usyd.edu.au/oztexts/parsons.html, items 3 and 4.

${ }^{46}$ To achieve inter-nation equity, P. Musgrave (2006) suggests that reciprocity should apply to both withholding taxes and business profits tax. rites:

The rate of tax applied at source should also be a matter of international agreement based on standards of internation equity. An obvious rule would be based on reciprocity, or internationally equal rates of tax on income accruing to nonresidents. Bilateral tax treaties usually call for reciprocally equal rates to be applied to withholding taxes, while profits are subject to a rule of non-discrimination between resident and non-resident taxpayers. For the standard of internation equity as proposed here, however, reciprocity should apply to such taxes in combination with withholding taxes. The rates applied to resident corporations are governed by domestic tax policy considerations, such as taxpayer equity and economic growth, whereas the rates applied to nonresidents should be determined by the appropriate share of their income earned at source, a share that should be set by international agreement and apply equally to all source countries. (at 176)

${ }^{47}$ See Thomas Franck, Fairness in International Law (1995) at 413-4. More recent studies confirm that the income gap is persistent and widening between the world's rich and poor countries: Donghyun Park, “Trends in the Income Gap Between 
Developed Countries and Developing Countries, 1960-1995,”

http://www3.ntu.edu.sg/nbs/sabre/working_papers/09-99.pdf.

${ }^{48}$ Brian Barry, The Theory of Justice (1973) 129-30. Since income taxation has been a major tool of redistribution in a domestic context in developed countries, in the age of globalization, it is worth exploring ways of using the income tax system to achieve international distributive justice.

49 Arthur J. Cockfield, 'The Rise of the OECD as Informal 'World Tax Organization' through National Responses to E-Commerce Tax Challenges,' Yale J. L. \& Tech. 9 (2006) 59.

${ }^{50}$ See, e.g., Joann Martens-Weiner, Company Tax Reform in the European Union: Guidance from the United States and Canada on Implementing Formulary Apportionment in the EU (New York: SpringerVerlag New York Inc, 2007).

${ }^{51}$ See Jinyan Li, 'Fundamental Enterprise Income Tax Reform in China: Motivations and Major Changes,' Bulletin for International Fiscal Documentation 61 (November 2007) 519; and Jinyan Li and He Huang, 'The Transformation of Chinese Enterprise Income Tax: International Tax Norms Hybridized with Chinese Innovations and Traditions,' Bulletin for International Fiscal Documentation 62 (2008) (forthcoming). ${ }^{52}$ See work cited in footnotes 1 and 2 ,

${ }^{53}$ Mitsuo Sato and Richard Bird, 'International Aspects of the Taxation of Corporations and Shareholders,' Staff Papers -Internaitonal Monetary Fund 22(2) (1975) 384; Hugh Ault, 'Corporate Integration, Tax Treaties and the Division of the International Tax Base: Principles and Practices,” Tax L. Rev. 47 (1991) 565; Anne Schafer and Christoph Spengel, 'The Impact of ICT on Profit Allocation within Multinational Groups: Arm’s Length Pricing or Formula Apportionment?' Discussion Paper No.0353 (Centre for European Economic Research) 6-7.

${ }^{54}$ See, e.g., Kaufman, 'Fairness and the Taxation of International Income'; Vogel, 'World-wide vs. Source Taxation of income.”

${ }^{55}$ Deborah Toaze, 'Tax Sparing: Good Intentions, Unintended Results,' Canadian Tax J. 49 (2001) 879 (stating that since the late 1960s and early 1970s, most of OECD members have included tax-sparing provisions in at least some of their tax treaties, on the basis that it is a component of an overall foreign aid 
policy aimed at promoting industrial, commercial, and scientific activities in developing countries). See also Samuel C. Thompson, Jr., 'The Case for Tax Sparing Along with Expanding and Limiting Subpart F Regime’,' Geo. Wash. Int'l L. Rev. 35 (2003) 303; Joseph P. Crockett, ‘Tax Sparing: A Legend Finally Reaches Print, National Tax Journal, ’ 11 (1958) 146; Damian Laurey, 'Reexamining U.S. Tax Sparing Policy with Developing Countries: The Merits of Falling in Line with International Norms, Virginia Tax Review 20 (2000) 467.

${ }^{56}$ See, e.g., Reuven Avi-Yonah, 'Globalization, Tax Competition, and The Fiscal Crisis of the Welfare State’; Brown, ‘Can Cross-Border Distribution Serve the Caribbean Region?’; and Easson, International Tax Reform and the Inter-Nation Allocation of Tax Revenue.

${ }^{57}$ Reuven S. Avi-Yonah, 'Bridging the North/South Divide: International Redistribution and Tax Competition,’ Mich. J. Int'l L. 26 (2004) 371 at 371 ('The events of September 11, 2001 demonstrate that we cannot expect to live in prosperity while others live in abject poverty.')

${ }^{58}$ See http://www.un.org/millenniumgoals.

${ }^{59}$ Yoram Margalioth, ‘Tax Competition, Foreign Direct Investments and Growth: Using the Tax System to Promote Developing Countries,' Va. Tax Rev. 22 (2003) 161; Avi Nov, 'Tax Incentives to Entice Foreign Direct Investment: Should There Be a Distinction Between Developed Countries and Developing Countries?' Va. Tax Rev. 23 (2004) 685; - The Bidding War' to Attract Foreign Direct Investment: The Need for a Global Solution,’ Va. Tax Rev. 25 (2006) 835.

${ }^{60}$ For example, the OECD's position may have some influence on the elimination of Chinese tax incentives earmarked for foreign investors; see Jinyan Li, 'The Rise and Fall of Chinese Tax Incentives and Implications for International Tax Debates,' Florida Tax Rev. (2007).

${ }^{61}$ Similar view is expressed by Arthur Cockfield, article

${ }^{62}$ Robert T. Kudrle and Lorraine Eden, 'The Campaign Against Tax Havens: Will It Last? Will It Work?' Stanford J. of Law, Business, and Finance (2003).

${ }^{63}$ Article 7 of OECD Model Convention. 
${ }^{64}$ For an overview, see Peter Mullins, 'Moving to Territoriality? Implications for the United States and the Rest of the World,” IMF Working Paper WP/06/161 (2006).

${ }^{65}$ Peggy Musgrave recognizes this problem and suggests more international coordination: Musgrave, ‘Sovereignty, Entitlement, and Cooperation in International Taxation,' at 1335-1356

${ }^{66}$ Drawing the line between business profits and investment income is extremely difficult in some cases. It is beyond the scope of this paper to fully explore this issue.

${ }^{67}$ In addition, such regimes enhance inter-nation equity from the perspective of the residence country which adopts the ability-to-pay principle. See Clifton Fleming, Jr., Robert J. Peroni and Stephen E. Shay, 'Fairness in International Taxation: The Ability-to-pay Case for Taxation Worldwide Income,” Florida T. Rev. 5 (2001) 299.

${ }^{68}$ OECD, Tax Sparing: A Reconsideration (1998). For more discussion, see Deborah Toaze, ‘Tax Sparing: Good Intentions, Unintended Results.”

${ }^{69}$ In terms of redistribution from high-income residence to low-income source countries, it was suggested that where a source country taxes the profit from a foreign investment but provides no relief for the loss, there is an implicit transfer from the residence country to the source country. The residence country bears the burden of recognizing the loss. The divergence between the tax treatment of the profit (source country taxing the upside of a risky investment while the residence country bears the burden of relief for the downside) is a crude tool for directing implicit transfers to the neediest recipients, and favours net capital importers. Another example of implicit wealth transfers to poor countries is where a developed country's tax policy encourages research and development which may lead to the discovery of new drug treatments that are ultimately shared with poorer nations under a favourable pricing regime. See Michell Kane, 'Risk and Redistribution in Open and Closed Economies,' http://taxprof.typepad.com/taxprof blog/files/Kane.doc (2006).

${ }^{70}$ See, for example, Flemming, Peroni and Shay, 'Fairness in International Taxation: The Ability-to-pay Case for Taxation Worldwide Income,’ 344-6; Thompson, Jr., ‘The case for Tax Sparing Along with Expanding and Limiting the Subpart F regime.' 